\title{
The role of social support and self-regulation on work readiness among students in vocational high school
}

Fatwa Tentama, Eva Riyansha Riskiyana

Faculty of Psychology, Universitas Ahmad Dahlan, Indonesia

\begin{tabular}{l} 
Article Info \\
\hline Article history: \\
Received Mar 9, 2020 \\
Revised Aug 1, 2020 \\
Accepted Oct 16, 2020 \\
\hline
\end{tabular}

Keywords:

Self-regulation

Social support

Work readiness

\begin{abstract}
Work readiness is an important factor that can determine the quality of prospective graduates and vocational high schools as one of the educational institutions that prepare human resources to need to pay attention to factors that can improve work readiness. This study aimed to empirically examine how social support and self-regulation influence the work readiness of vocational High School students. The population in this study was all students of grade XII in Vocational High School Muhammadiyah 1 Yogyakarta (a vocational high school), totaling 170 students, and the sample of this study was 111 students. The sampling technique used was randomized sampling using cluster random sampling technique. The data were collected with the work readiness scale, social support scale, and self-regulation scale. The data were then analyzed with multiple linear regression techniques. There was a very significant correlation between social support and selfregulation and they simultaneously influence work readiness $(r=0.490, p=$ 0.000 ). There was a very significant correlation between social support and work readiness $(r=0.344, p=0.000)$. There is a very significant correlation between self-regulation and work readiness $(r=0.490, p=0.000)$. Selfregulation plays dominant role in shaping work readiness.
\end{abstract}

This is an open access article under the CC BY-SA license.

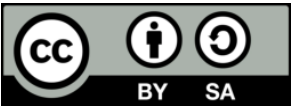

\section{Corresponding Author:}

Fatwa Tentama,

Faculty of Psychology,

Universitas Ahmad Dahlan,

Kapas Street 9, Semaki, Yogyakarta, Indonesia.

Email: fatwa.tentama@psy.uad.ac.id

\section{INTRODUCTION}

Work readiness is an important factor that must be possessed by every individual because work readiness is one of the criteria for measuring the appropriateness of individual work quality with the needs of the workforce [1]. Work readiness is able to facilitate individuals to identify career opportunities and predict success so as to enable them to find jobs either directly or indirectly [2]. Work readiness will encourage individuals to improve their work mobility and helps produce human resources who are more flexible, skilled, qualified, and able to be employed. Eventually, it is hoped that they are able to meet the requirements of the job market [3].

People need to have high work readiness to develop emotional and social attributes in deepening conceptualizations and practices that enable them to find work in the future [4]. Individuals with work readiness tend to have the commitment and willingness to engage in self-change related to the work they want [5]. Work readiness is one of the important factors that must be possessed by vocational high school graduates to enter the workforce. However, the realities in the field show the opposite in which many employers find that some graduates lack work readiness for long-term success [6]. 
Work readiness refers to the extent to which individuals are considered to have the knowledge and skills to work independently [7]. Work readiness is described as an individual's readiness to adjust to the cultural demands at work [8]. It is a bridge that connects work-oriented learning with skills needed by the world of work [4]. Work readiness as a skill and attribute that makes an individual ready for success at work and is increasingly recognized as an indication of the potential in terms of job performance and career progression [9]. It also informs the extent to which individuals have attitudes, skills, and knowledge that can help them prepare for success at work [10].

There are many factors that influence work readiness, one of which is social support [11]. Social support is able to facilitate the decision-making process in exploring individual careers [12]. It is believed that individuals need help from the surrounding environment, such as friends, teachers, parents, and people who have the capacity in a specific fields in planning their careers [13]. Some researchers find that without adequate social support, individuals are lacking work readiness, and therefore to have better work readiness, they really need social support [14]. Social support is a potential resource for getting career-specific advice and information and addressing the changing demands of the world of work, such as reducing career problems and strengthening self-regulatory capacity in career development [15].

When students do not get information, advice and feedback from teachers or parents in the learning process at school, it will make it difficult for students to adapt to the tasks given at school. This will affect student learning outcomes or student work practices. Of course this can have a long-term impact when students finally get a job. In addition, when teaching and learning activities in schools do not get learning facilities that support and appropriate education services, it will affect the activity and readiness to face changes in the tasks and time of task completion. Thus social support is needed in achieving maximum work readiness, when individuals get maximum social support then the individual will be better prepared to work later.

Social support is an interactive process that can enhance coping, respect, ownership, and abilities through the actual or perceived exchange of physical or psychosocial resources [16]. Social support is described as providing assistance or comfort to others aimed at helping to overcome various biological, psychological, and social stressors [17]. Social support contains a multidimensional collection of material, emotional, or information resources. These resources are provided through social relationships with family, friends, groups, or professionals [18]. It is also seen as assistance received by individuals generally in terms of moral, emotional, guidance, friendship, and togetherness. This support can be facilitated through social activities, guiding relationships, friendship, the process of giving advice, offering to listen, and consolation [19].

Another factor that is believed to play a role in improving work readiness is self-regulation. Selfregulation is an outcome-oriented concept and goals. This concept facilitates individual psychology in preparing to enter the workforce [20]. Self-regulation in the context of work readiness is shown by being an independent person in managing careers, setting goals, and implementing them. It makes individuals feel more capable and confident about their actions and behavior to achieve certain career outcomes that lead to career success [21]. Individuals who are unable to manage themselves and are unable to utilize or create learning environments that support their learning achievement will find it difficult to adapt to changes in school schedules and tasks and difficult to manage their study time. In addition, if individuals do not have learning targets, have never evaluated the achievement of these targets and do not have high confidence to do so, they will not have maximum work readiness, minimal skills, low quality of learning outcomes and low self-confidence in completing their tasks. Thus, self-regulation is very necessary in achieving maximum work readiness, when individuals have good self-regulation; the individual will be better prepared to work later.

Self-regulation is defined as the ability to control and regulate impulses to set and achieve long-term goals [22]. It is also seen as the ability to control emotions and behavior through monitoring, inhibition, and self-evaluation according to standards in the social environment of individuals [23]. Self-regulation is the capacity of individuals to change their behavior with the aim of increasing flexibility and adaptability in adjusting to social and situational demands [24]. Self-regulation includes cognitive, behavioral, temperamental, and social, emotional components that involve the focus of attention, initiating actions, thoughts, and emotions and monitoring the results to achieve certain goals [25]. This study aimed to empirically examine the role of social support and self-regulation in predicting the work readiness of students at the Vocational High School Muhammadiyah 1 Yogyakarta. 


\section{RESEARCH METHOD}

\subsection{Population, sample, and sampling technique}

The population in this study was all students of grade XII of Vocational High School Muhammadiyah 1 Yogyakarta totaling 170 students, and the sample of this study was 111 students. In choosing the sample, the researcher considers the fact that students in grade XII had an adequate understanding and skills because they had completed the job training or internship. The sampling technique used in this study was a cluster random sampling technique and focuses on four classes as research samples from the accounting and multimedia major, consisting of class XII AK2, Mm1, Mm2, and Mm3.

\subsection{Measuring instrument}

The methods of data collection in this study are self-designed scale, including work-readiness scale, social support scale, and self-regulation of scale. Job readiness scale is composed by referring to the job readiness concept of Brady's [26], namely: responsibility, flexibility, communication skills, self-esteem, health, and personal safety. The scaling model used for this scale is Likert-scale model. The sample items on this scale are: "I can do the job according to the teacher's instructions", "I am able to use the practice tools according to the procedure", and "I am willing to learn new things to improve my skills".

Social support is designed based on aspects of social support, according to Solomon [27]: emotional support, instrumental support, and supportive information. This scale also uses a Likert scale model. Examples of items on the social support scale are: "My friends are willing to help when I need them", "My friends give me information when I need it", and "my membership is appreciated by my friends at school".

The scale of self-regulation is expressed based on the aspects of self-regulation, according to Zimmerman [28], namely: metacognition, motivation, and behavior. Likert scaling model is also used for this scale. Examples of self-regulation scale items are: "I have clear goals after graduation", "I can concentrate on learning easily", and "I evaluate what I have achieved."

\subsection{Validity and reliability of measuring instruments}

The data were collected with the work readiness scale, social support scale, and self-regulation scale. Data retrieval is done in a classical way to the sample of this study directly. The scale is given directly to the participant, and then participants are asked to fill in the scale and after the scale are collected simultaneously. Data is inputted and analyzed using Cronbach's alpha. Cronbach's alpha is used to measure the reliability of the indicators used in the research scale.

The results of the trial analysis of 59 subjects on the work readiness scale yielded a reliability coefficient $(\alpha)$ of 0.900 with a corrected item-total correlation index ranging from 0.313 to 0.643 . The valid and reliable items to be used for this study are 28 items. Results of a trial of 59 subjects on the social support scale resulted in a 0.946 reliability coefficient $(\alpha)$ with a corrected item-total correlation index ranging from 0.303 to 0.818 . The valid and reliable items to be used for the study were 33 items. The trial results of the 59 subjects on the self-regulation scale resulted in a 0.915 reliability coefficient $(\alpha)$ with a corrected item-total correlation index ranging from 0.338 to 0.759 . The valid and reliable items to be used for this study are 28 items.

\subsection{Data analysis}

The parametric statistical method is the method used for data analysis. Data analysis was performed with IBM SPSS Statistics 21.0, using multiple regression techniques, which is a statistical analysis technique to identify the role of social support and self-regulation in predicting work readiness.

\section{RESULTS AND DISCUSSION}

\subsection{Prerequisite test}

The prerequisite test was carried out before analysis with multiple regression techniques, namely the normality test, linearity test and multicollinearity test.

\subsubsection{Normality test}

Normality test is done with the aim to assess the distribution of data in groups of data or variables, whether the data distribution is normally distributed or not. Normality test is useful for determining data that has been collected in normal distribution or taken from a normal population. Based on the results of the normality analysis shown in Table 1 , it is known that the significance values of work readiness, social support, and self-regulation are $0.622,0.813$, and 0.567 , which had $p>0.05$. It means that each data is normally distributed. 
Table 1. Distribution normality test

\begin{tabular}{cccc}
\hline Variable & Score K-SZ & Sig. & Explanation \\
\hline Work readiness & 0.753 & 0.622 & Normal \\
Social support & 0.636 & 0.813 & Normal \\
Self-regulation & 0.786 & 0.567 & Normal \\
\hline
\end{tabular}

\subsubsection{Linearity test}

Linearity test aims to determine whether two variables have a linear correlation or not significantly. A linear correlation shows that changes in predictor variables will tend to be followed by changes in criterion variables by forming linear lines. Based on Table 2, the linearity test resulted in F Linearity of 17.562 with a significance level (p) of 0.000 . Self-regulation on work readiness earned F Linearity of 38.453 with a significance level (p) of 0.000 , and it can be said to be linear. Thus, social support and self-regulation influence work readiness, and there is a line which connects them.

Table 2. Linearity test

\begin{tabular}{ccccc}
\hline Variable & F Linearity & Sig. & Criteria & Explanation \\
\hline Social support & 17.562 & 0.000 & $\mathrm{p}<0.05$ & Linear \\
Self-regulation & 38.453 & 0.000 & $\mathrm{p}<0.05$ & Linear \\
\hline
\end{tabular}

\subsubsection{Multicollinearity test}

Multicollinearity test is used to find out whether or not there is a deviation from the classic assumption of multicollinearity, namely the existence of a linear correlation between the independent variables in the regression model. The prerequisite that must be fulfilled in the regression model is the absence of multicollinearity. As shown in Table 3, the VIF value for social support and self-regulation is 1.918 (VIF < 10) with a tolerance of 0.521 (tolerance > 0.1) It thus informs that there is no multicollinearity between the two variables.

Table 3. Multicollinearity test

\begin{tabular}{cccc}
\hline Variable & Tolerance & VIF & Explanation \\
\hline Social support & 0.521 & 1.918 & No Multicollinearity \\
Self-regulation & 0.521 & 1.918 & No Multicollinearity \\
\hline
\end{tabular}

\subsection{Multiple linear regression analysis}

Testing the hypothesis proposed in this study done using multiple linear regression analysis. Multiple Linear regression analysis is used to measure the effect of more than one predictor variable (the independent variable) on the dependent variable. Table 4 informs that the role of social support in work readiness is rated as 0.344 with a significance level of $\mathrm{p} 0.000(\mathrm{p}<0.01)$, which means that there is a very significant correlation between social support and work readiness. The role of self-regulation on work readiness is rated as 0.490 with a $p$-value of $0.000(p<0.01)$, which means that there is a significant correlation between self-regulation of work readiness.

Table 4. Partial analysis test

\begin{tabular}{ccccc}
\hline Variable & Partial & Sig. & Rule & Explanation \\
\hline Social support to work readiness & 0.344 & 0.000 & $\mathrm{P}<0.01$ & There's a significant role \\
Self-regulation to work readiness & 0.490 & 0.000 & $\mathrm{P}<0.01$ & There's a significant role \\
\hline
\end{tabular}

Based on the results of multiple linear regression analysis in Table 5, it is found that social support and self-regulation can simultaneously contribute to the work readiness of students in Vocational High School Muhammadiyah 1 Yogyakarta. These results indicate that the first hypothesis is accepted so that social support and self-regulation can predict work readiness. Simultaneously, social support and selfregulation contributed $35.8 \%$ to work readiness, and the remaining $64.2 \%$ was from other factors. Other factors that influence work readiness include learning achievement and self-concept [29], career management practices, work experience, training [30], soft-skills, problem-solving skills, internship experience, and special expertise factors [31]. The contribution of social support to work readiness is $11.8 \%$, and the contribution of self-regulation to work readiness is $24 \%$ so that self-regulation contributes more dominantly to work readiness than social support.

The role of social support and self-regulation on work readiness among students in ... (Fatwa Tentama) 


\begin{tabular}{cccccc}
\multicolumn{7}{c}{ Table 5. Multiple linear regression analysis } \\
\hline Variable & $\mathrm{R}$ & $\mathrm{R}$ Square & Sig. & Criterion & Explanation \\
\hline $\begin{array}{c}\text { Social support and self-regulation } \\
\text { on work readiness }\end{array}$ & 0.490 & 0.240 & 0.000 & $\mathrm{P}<0.01$ & $\begin{array}{c}\text { There's a very } \\
\text { significant role }\end{array}$ \\
\hline
\end{tabular}

The results of the analysis also show that the second hypothesis is accepted, which means there is a correlation between social support and the work readiness of students. This result is in line with the findings of previous research, which also found that social support contributes to the level of student work readiness [31-33]. Social support is a very important source of strength possessed by every individual in the career development process [34]. Social support will facilitate an individual's work readiness, and with the availability of social support, people will find it easier to plan a career and prepare to enter the workforce. Therefore in the context of work readiness, every individual needs to have sufficient social support [35].

Social support works as a psychological resource that will help increase individual work readiness to cope with stress and the perception of the possibility of not getting work [36]. This kind of support acts as a social network that can provide information and services related to individual career development needs. In addition, social support will facilitate individuals during the job search process, and thus the availability of this support makes individuals more ready to find work [37]. The support provided by the teacher is very meaningful for students in the learning process, this social support will facilitate individual career development by providing career knowledge information that is relevant to the needs of the working world today [38]. Students who get information, advice and feedback from teachers or parents in the learning process at school, it will make it easier for students to adapt to their learning environment and assignments given at school. This form of support from teachers and parents will influence student learning outcomes or student work practices. Of course, this can have a long-term positive impact when students finally get a job.

The results in the third hypothesis are accepted, which means that self-regulation plays a role in shaping the work readiness of students. This finding is in line with the results of previous studies, which found that self-regulation is responsible for the level of employee work readiness [39, 40]. Self-regulation enables individuals to move quickly and easily through challenges found in career contexts [41]. Individuals who have self-regulation tend to be more innovative, proactive, and motivated to achieve their goals [42]. The energy generated by self-regulation is focused on continuing career learning to keep up with the latest developments related to the career he wants [43].

Self-regulation helps individuals to achieve effective results in managing careers [41], by setting career goals and action plans directed at an individual who will be actively willing to find information about the career he wants [42, 44-46]. Self-regulation facilitates individual beliefs and expectations in finding work [47], by fostering an attitude of responsibility for his career [47, 48], that they have independence and responsibility for their decisions and eventually believe that their efforts were able to produce results in the future [14]. Students who have learning targets, evaluate the achievement of these targets and are supported by confidence to complete them, students will have good work readiness, have good skills, appropriate quality of learning outcomes and confidence in completing their assignments. In addition, students who are able to organize themselves, are able to utilize and create a learning environment that supports their learning achievement will be easy to adapt to the demands on school schedules and assignments and easily manage their study time.

The findings of this study are different from previous studies. The results of previous studies that examined workreadiness found that factors related to workreadiness were self-concept and perception of the learning environment [49], entrepreneur intention and responsibility [50, 51], academic achievement and self-concept [29], motivation to learn and social support [11]. This research is expected to develop the results of previous research to be more comprehensive in uncovering the problems of student work readiness. This research can provide insight and awareness to students and teachers. This research shows that social support and self-regulation can make individuals more ready to enter the workforce because of the availability of a series of facilities from the support of the surrounding environment and the drive within to obtain maximum results. Vocational education institutions need to consider factors of social support and self-regulation in preparing their students for the workforce. The results of this study can also be used as a reference for developing self-regulation training modules because self-regulation has a more dominant contribution in improving student work readiness. Thus, it is hoped that students will have better readiness to enter the world of the work market. 


\section{CONCLUSION}

Social support and self-regulation are important variables in shaping work readiness. Simultaneous social support and self-regulation are able to contribute to the level of work readiness of students in Vocational High School Muhammadiyah 1 Yogyakarta. Self-regulation plays a more dominant role to work readiness by $24 \%$, while social support has a smaller influence (11.8\%). Internal factors play a more important role than external factors in the development of student work readiness. Student self-regulation must be the main concern of schools and parents as a strategy for handling student work readiness problems.

\section{ACKNOWLEDGEMENTS}

The authors would like to thank the Psychology Study Program, Universitas Ahmad Dahlan and Vocational High School Muhammadiyah 1 Yogyakarta for the technical assistance in this study. The authors also thank all participating students, teachers, school administrators, and other individuals for their efforts, assistance, and involvement in this research.

\section{REFERENCES}

[1] A. P. Sasmito, "Work readiness of software engineering student in Batu City," Proceedings of the 1st International Conference on Vocational Education and Training (ICOVET 2017), vol. 116, pp. 67-70, 2017.

[2] R. E. Landrum, P. I. Hettich, and A. Wilner, "Alumni perceptions of workforce readiness," Teaching of Psychology, vol. 37, no. 2, pp. 97-106, 2010.

[3] J. Andrews, and H. Higson, "Graduate employability, 'soft skills' versus 'hard'business knowledge: A European study," Higher Education in Europe, vol. 33, no. 4, pp. 411-422, 2008.

[4] S. Bandaranaike, and J. W. Willison, "Building capacity for work-readiness: Bridging the cognitive and affective domains," Asia-Pacific Journal of Cooperative Education, vol. 16, no. 3, pp. 223-233, 2015.

[5] M. Farkas, and D. Nicolellis, Fostering readiness for rehabilitation and employment. Boston: Springer. 2004.

[6] J. Casner-Lotto, and L. Barrington, Are they really ready to work? New York: The Conference Board, Inc. 2006.

[7] T. Levett-Jones, J. Gersbach, C. Arthur, and J. Roche, "Implementing a clinical competency assessment model that promotes critical reflection and ensures nursing graduates' readiness for professional practice," Nurse Education in Practice, vol. 11, no. 1, pp. 64-69, 2011.

[8] A. J. Parker, "Career and technical education and workplace readiness of high school students," (Doctoral Dissertation). University of Georgia. Athena. 2011.

[9] C. L. Caballero, et al., "The work readiness scale (WRS): Developing a measure to assess work readiness in college graduates," Journal of Teaching and Learning for Graduate Employability, vol. 2, no. 2, pp. 41-54, 2011.

[10] D. Kwok, M. Gujral, and J. Chan, "Work readiness: A study of student intern's self-perception and supervisor evaluation," International Conference on Teaching \& Learning in Higher Education, pp. 1-3, 2014.

[11] F. Tentama, Subardjo, and M. H. Abdillah, "Motivation to learn and social support determine employability among vocational high school students," International Journal of Evaluation and Research in Education, vol. 8, no. 2, pp. 237-242, 2019.

[12] Z. Jiang, "Social support and career psychological states: an integrative model of person-environment fit," Journal of Career Assessment, vol. 25, no. 2, pp. 219-237, 2017.

[13] S. Patel, et al., "Career decision-making self-efficacy of Vietnamese adolescents: The role of acculturation, social support, socioeconomic status, and racism," Journal of Career Development, vol. 34, no. 3, pp. 218-240, 2008.

[14] M. Clarke, and M. Patrickson, "The new covenant of employability," Employee Relations, vol. 30, no. 2, pp. 121-141, 2008.

[15] P. Creed, et al., "Causal relationship between career indecision and career decision-making self-efficacy: A longitudinal cross-lagged analysis," Journal of Career Development, vol. 33, no. 1, pp. 47-65, 2006.

[16] S. Cohen, L. G. Underwood, and B. H. Gottlieb, Social support measurement and intervention: A guide for health and social scientists. New York: Oxford University Press, 2000.

[17] American Psychological Association, APA dictionary of psychology. Washington: American Psychological Association. 2007

[18] J. G. Harris, "Self-esteem, family support, peer support, and depressive symptomatology: A descriptive correlational study of pregnant adolescents," (Doctoral Dissertation). Georgia State University. Georgia. 2006.

[19] L. Mantai, and R. Dowling, "Supporting the PhD journey: Insights from acknowledgements," International Journal for Researcher Development, vol. 6, no. 2, pp. 106-121, 2015.

[20] O. P. John, and J. J. Gross, "Healthy and unhealthy emotion regulation: Personality processes, individual differences, and life span development," Journal of Personality, vol. 72, no. 6, pp. 1301-1334, 2004.

[21] M. Coetzee and L. Engelbrecht, "How employability attributes mediate the link between knowledge workers' career adaptation concerns and their self-perceived employability," Psychological Reports, vol. 123, no. 4, pp. 1-22, 2019.

[22] B. J. Zimmerman, Attaining self-regulation: A social cognitive perspective. Massachusetts: Academic Pres, 2000.

[23] C. M. Aldwin, et al., "Coping and self-regulation across the lifespan," In Fingerman, K. L., Berg, C., Smith, J., and Antonucci, T. C. (Eds.), Handbook of life-span development. New York: Springer Publishing Company, 2011. 
[24] R. F. Baumeister, and K. D. Vohs, "Self-Regulation, ego depletion, and motivation," Social and Personality Psychology Compass, vol. 1, no. 1, pp. 115-128, 2007.

[25] M. M. McClelland and C. E. Cameron, "Self-regulation and academic achievement in elementary school children," New Directions for Child and Adolescent Development, vol. 133, pp. 29-44, 2011.

[26] R. P. Brady, "Work readiness inventory, administrator guide," JIBT Works, pp. 1-6, 2009.

[27] P. Solomon, "Peer support/peer provided services underlying processes, benefits, and critical ingredients," Psychiatric Rehabilitation Journal, vol. 27, no. 4, pp. 392-401, 2004.

[28] B. J. Zimmerman, "Becoming a self-regulated learner: An overview," Theory into Practice, vol. 41, no. 2, pp. 64-70, 2002.

[29] F. Tentama and M. H. Abdillah, "Student employability examined from academic achievement and self-concept," International Journal of Evaluation and Research in Education (IJERE), vol. 8, no. 2, pp. 243-248, 2019.

[30] N. Juhdi, F. Pa'Wan, N. A. Othman, and H. Moksin, "Factors influencing internal and external employability of employees," Business and Economics Journal, vol. 11, pp. 1-10, 2010.

[31] D. J. Finch, L. K. Hamilton, R. Baldwin, and M. Zehner, "An exploratory study of factors affecting undergraduate employability," Education + Training, vol. 55, no. 7, pp. 681-704, 2013.

[32] L. T. Eby, M. Butts, and A. Lockwood, "Predictors of success in the era of the boundaryless career," Journal of Organizational Behavior, vol. 24, no. 6, pp. 689-708, 2003.

[33] S. McArdle, L. Waters, J. P. Briscoe, and D. T. T. Hall, "Employability during unemployment: Adaptability, career identity and human and social capital," Journal of Vocational Behavior, vol. 71, no. 2, pp. 247-264, 2007.

[34] J. Masdonati, K. Massoudi, and J. Rossier, "Effectiveness of career counseling and the impact of the working alliance," Journal of Career Development, vol. 36, no. 2, pp. 183-203, 2009.

[35] D. J. Brown, et al., "Proactive personality and the successful job search: A field investigation with college graduates," Journal of Applied Psychology, vol. 91, no. 3, pp. 717-726, 2006.

[36] B. Van der Heijden, A. Kümmerling, K. Van Dam, E. Van der Schoot, M. Estryn-Béhar, and H. Hasselhorn, "The impact of social support upon intention to leave among female nurses in Europe: Secondary analysis of data from the NEXT survey," International Journal of Nursing Studies, vol. 47, no. 4, pp. 434-445, 2010

[37] P. K. Adraki, et al., "Social networks and employability in the Tamale Metropolis of the Northern Region, of Ghana," Journal of Agricultural Economics and Rural Development, vol. 4, no. 1, pp. 357-364, 2018.

[38] P. Parker, M. B. Arthur, and K. Inkson, "Career communities: A preliminary exploration of member-defined career support structures," Journal of Organizational Behavior, vol. 25, no. 4, pp. 489-514, 2004

[39] F. Lee, et al., "Personality and the goal-striving process: the influence of achievement goal patterns, goal level, and mental focus on performance and enjoyment," Journal of Applied Psychology, vol. 88, no. 2, pp. 256-265, 2003.

[40] C. L. Porath, and T. S. Bateman, "Self-regulation: from goal orientation to job performance," Journal of Applied Psychology, vol, 91, no. 1, pp. 185-192, 2006.

[41] M. Coetzee, "Exploratory factor analysis of the employability attributes scale: Adaptation toward the EAS 2.0," (Research Report). Department of Industrial and Organisational Psychology. University of South Africa. South Africa, 2018.

[42] M. Bezuidenhout, "The development and evaluation of a measure of graduate employability in the context of the new world of work," (Dissertation). Department of Human Resources. University of Pretoria. Pretoria. South Africa, 2011.

[43] M. A. Uy, et al., "Proactivity, adaptability and boundaryless career attitudes: The mediating role of entrepreneurial alertnes," Journal of Vocational Behavior, vol. 86, no. 1, pp. 115-123, 2015.

[44] M. Bezuidenhout, and M. Coetzee, "Preliminary exploratory factor analysis: Student employability scale," (Research Report). Department of Industrial and Organisational Psychology. University of South Africa. Pretoria. South Africa. 2010.

[45] A. De Vos, and N. Soens, "Protean attitude and career success: The mediating role of selfmanagement," Journal of Vocational Behavior, vol. 73, no. 3, pp. 449-456, 2008.

[46] P. Wesarat, M. Y. Sharif, and A. H. A. Majid, "A review of organizational and individual career management: A dual perspective," International Journal of Human Resource Studies, vol. 4, no. 1, pp. 101-113, 2014

[47] M. Du Toit, "Exploring experiences of unemployment in South African townships," (Thesis). North-West University. Potchefstroom. South Africa. 2018.

[48] D. E. De Souza, "Culture, context and society: The underexplored potential of critical realism as a philosophical framework for theory and practice," Journal of Social Psychology, vol. 17, no. 2, pp. 141-151, 2014.

[49] F. Tentama, and H. D. Jayanti, "Self-concept, perception of the learning environment and employability: A study of vocational high school students in Prambanan Yogyakarta, Indonesia," Humanities \& Social Sciences Reviews, vol. 7, no. 1, pp. 433-440, 2019.

[50] F. Tentama and S. Yusantri, "The role of entrepreneurial intention in predicting vocational high school student's employability," International Journal of Evaluation and Research in Education, vol. 9, no. 3, pp. 558-563, 2020.

[51] F. Tentama and N. Merdiaty, "Analysis of factors that affect employability and its implications," Humanities \& Social Sciences Reviews, vol. 8, no. 3, pp. 238-245, 2020. 